\title{
Perceptions of Biosecurity-Based Accreditation in the Plant Trade: A UK Example
}

\author{
Mariella Marzano *(1), Michael Dunn (1) and Sarah Green \\ Forest Research, Northern Research Station, Roslin EH25 9SY, UK; michael.dunn@forestresearch.gov.uk (M.D.); \\ sarah.green@forestresearch.gov.uk (S.G.) \\ * Correspondence: Mariella.marzano@forestresearch.gov.uk
}

check for updates

Citation: Marzano, M.; Dunn, M.; Green, S. Perceptions of BiosecurityBased Accreditation in the Plant Trade: A UK Example. Forests 2021, 12, 1741. https://doi.org/10.3390/ f12121741

Academic Editor: Benedetto T. Linaldeddu

Received: 26 September 2021

Accepted: 1 December 2021

Published: 10 December 2021

Publisher's Note: MDPI stays neutral with regard to jurisdictional claims in published maps and institutional affiliations.

Copyright: (c) 2021 by the authors. Licensee MDPI, Basel, Switzerland. This article is an open access article distributed under the terms and conditions of the Creative Commons Attribution (CC BY) license (https:/ / creativecommons.org/licenses/by/ $4.0 /)$.
Abstract: It is widely acknowledged that a major threat to tree health biosecurity comes from trade, particularly through the importation of containerised live plants and associated growing media. Nurseries can collectively play a key role in mitigating pests and diseases through attention to their daily practices (e.g., procuring plants, storage and management). More widespread adoption of best practices in the sector could be promoted through the introduction of a UK-wide accreditation scheme. However, the success of such a scheme would depend not only on its uptake by nurseries but also on the attitudes of key consumers in the plant supply chain. To date, the perspectives of the nursery sector on the feasibility of plant biosecurity, as well as the sensitivity of these sectors to consumer opinion, have remained under-researched. Using the COM-B [Capability, Opportunity, Motivation-Behaviour] model as a framework, we draw on qualitative results to assess the appetite for a hypothetical accreditation scheme amongst UK nurseries and the capability, opportunities and motivations to enhance their biosecurity practices. Nineteen semi-structured interviews were conducted with plant nurseries and 22 with their consumers. Overall a plant health accreditation scheme should have actions that are: (1) viable within the confines of the site and supply chain; (2) affordable where the benefits of changes/improvements outweigh the costs; (3) beneficial in that they promote biosecurity; (4) attractive to consumers looking to purchase products from accredited nurseries; (5) fair and inclusive where everyone has responsibility for biosecurity; (6) transparent with the scheme involving a strong monitoring and auditing component. This study provides important insights that will feed into the development of plant biosecurity-focussed accreditation or certification.

Keywords: plant health; biosecurity; accreditation; COM-B framework; nurseries

\section{Introduction}

Awareness of the environmental, economic and social impacts from plant pests and diseases is on the increase amongst horticulture and forestry sectors [1,2]. The substantial trade in plant commodities has been implicated in the introduction and spread of pests and diseases across the globe, which is exacerbated further by climatic changes and management practices $[3,4]$. In the UK, relatively recent examples include ash dieback caused by the fungal pathogen Hymenoscyphus fraxineus and Phytophthora ramorum, with the spread of Phytophthora pathogens in traded plants and accumulating in plant nurseries a particular problem due to their extensive host ranges and ability to persist in soil and water [5-7]. Indeed, a recent study investigating Phytophthora diversity in UK plant nurseries found 63 different Phytophthora species including quarantine regulated pathogens and species not previously recorded in the UK, highlighting the need for improved biosecurity across the plant trade [8]. Early detection of pests and diseases is notoriously difficult [9] and relies on extensive surveillance and monitoring systems, often resourced by government inspection and related research. While a surveillance network acts as an essential early warning system, an additional preventative approach focuses on improving the knowledge and biosecurity behaviours of key industry sectors through a shared set of agreed 
standards. This article explores the motivations and challenges of belonging to a voluntary accreditation scheme from the perspective of nurseries and their consumers, specifically Local Authorities who purchase plants for public land and commercial operators such as garden centres and non-specialist retailers.

We used the term accreditation in this research to indicate a set of biosecurity standards and code of conduct which nurseries would sign up to, although terms such as assurance and certification are also used more broadly to describe various schemes. Examples include the Nursery Industry Accreditation Scheme in Australia [10], the New Zealand Plant Pass Scheme [11], the Global GAPP trademark and certification [12] as well as the Plant Healthy Certification Scheme [13] and the Ornamental Horticulture Assurance Scheme [14] in the UK. The differences between these terms are nuanced, accreditation and certification are sometimes used interchangeably but they are identified as distinct steps towards quality assurance. The United Kingdom Accreditation Service (UKAS) defines certification as a third party audit to assess whether an organisation has conformed to a specific set of standards. Accreditation is defined as recognition from an independent third party "that an organisation has the competence and impartiality to perform specific technical activities such as certification, testing and inspection" [15]. Membership of a scheme acknowledges that businesses have met the required biosecurity governance and standards while adoption by many businesses at a broader scale has the strong potential to fundamentally change practices within the plant supply chain.

There has been some analysis on the efficacy of voluntary certification, accreditation and assurance schemes in forums such as eco-labelling (a mark of environmental or sustainability credentials) to encourage sustainable behaviours in a range of food and forestry sectors. Some of the first eco-labelling initiatives, such as the German Blue Angel (1977), the Canadian Environmental Choice (1988), the Nordic Swan (1989) and the European Flower (1992), were introduced by governments to apply to a wide range of products. Although schemes in Germany and the Nordic countries proved reasonably successful in terms of industry participation, many government-sponsored programmes suffered low take-up by producers and retailers and garnered little interest from consumers [16]. Experiences from other sectors such as food assurance schemes identified that consumers question the practicality of monitoring complex supply chains while expressing confusion and scepticism about how well the schemes can work in practice [17]. Owing to such issues, the majority of eco-labelling initiatives for food products have fallen short of providing a credible quality assurance scheme in the minds of consumers [18]. Zaman et al. [19] contend that environmental impact remains an important criterion for consumers while making purchasing decisions and that environmental labelling is an important tool in facilitating responsible purchasing. Unfortunately, this tool often fails to communicate the desired message to consumers. Fearne et al. [20] similarly found that assurance schemes in Germany and Italy have the potential to reduce perceived risk and increase consumer confidence in specific fresh beef products, but that considerable scope remains for improving the communication for the schemes' objectives to be clearly understood. Such findings underline the importance of labelling a product with a well-known certification logo that consumers recognise, understand and trust [21].

Despite a number of challenges, some of the more recent certification and labelling programmes developed by non-government organisations and industry associations in response to environmental and social concerns in farming, fishing, forestry, tourism, mining and others have been able to demonstrate some success [16]. Today, accreditation, certification and assurance schemes have successfully carved out a share of numerous UK markets, with examples including fair-trade coffee and chocolate, Soil Association organic produce, Lion Eggs, Red Tractor produce and sustainable forests and wood products to name but a few. For example, a UK-based review [22] provided an early assessment of the appetite for labelling/certification schemes and explored the effectiveness of existing schemes. Grown in Britain (GiB) and the Forest Stewardship Council (FSC) were two of the schemes included in the review [22]. GiB stipulates that timber must be grown 
in the UK in accordance with the UK Forestry Standard [23] for businesses to receive certification. Compliance is independently audited. The acknowledged benefit is that producing rather than importing planting stock reduces pest and diseases risks. It also broadens participation beyond growers to different sectors along the supply chain as proof of where they have sourced material from. However, there is a potential that stringent requirements on sources may limit business opportunities with the challenge that not all plant material can currently be produced in the UK due to capacity, climate or cost. While FSC primarily covers forest and wood products, it provides a useful example of a global standard for sustainable and ethically managed forests [24]. FSC certification involves a chain-of-custody auditing process that tracks the origin of forest products through the supply chain as an assurance that they meet the required standards [24]. However, there have been claims of excessive bureaucracy and that the purpose of the labelling is not well understood by consumers [22]. There are also cost barriers to improving standards and auditing at every stage of the supply chain, although FSC have attempted to address some of these issues through, for example, group certification and allowing labelling to identify what proportion of their product is FSC certified.

A recent review of voluntary environmental certification or accreditation schemes identified key principles that contribute to a scheme's effectiveness [25]. Three key principles stood out as important to a scheme's success: (1) participation, (2) standards and, (3) monitoring. The participation component involves recruitment and maintenance of membership, particularly the benefits that may offset the cost of membership. The authors found that access to information and technical guidance on actions was a key motivation but added that attracting environmentally aware consumers and investors and increasing credibility may also be an incentive. The range and complexity of the standards are crucial for the effectiveness of any scheme. Stringent standards can increase the legitimacy and reputation of the programme, which in turn could increase participation but if they are too stringent then the costs of complying may outweigh the benefits [26]. Curtis et al. [25] noted that the literature had yet to identify an optimal balance and suggest that a scheme should include reflections on how to improve practices and whether the social, environmental and economic impacts of a scheme are acceptable. Within the monitoring principle, there was recognition that businesses could use the scheme as a tick box exercise. Some thought is needed on how to monitor or police compliance amongst the membership and schemes are more effective if they are backed up by new or existing regulations. In addition, pro-environmental behaviours can be encouraged through peer pressure and the creation of shared social norms and values, but it is unclear how this could be measured [25].

Biosecurity across the plant supply chain is likely to improve if there is a common agreement and understanding of best practice behaviours to mitigate against the introduction and spread of pests and diseases. Our research coincided with the development of what is now called the UK Plant Healthy Certification Scheme [13]. While both pieces of work were conducted separately, there was continued communication between the researchers and the founders of the scheme. Certainly, there is a strong appetite in the UK to encourage key players in the supply chain to take responsibility for improving their biosecurity practices as evidenced by the UK Tree Health Resilience Strategy [27] and the more recent England Trees Action Plan (2021-2024) [28]. The latter seeks to dramatically increase tree cover and makes a direct call for people to purchase plants from nurseries that are following recognised plant health standards. The Plant Healthy certification scheme is in its infancy but has already had a soft launch, encouraging businesses to undertake a biosecurity self-assessment and to join the scheme. As members, businesses will follow the plant health management standard, be independently audited (led by GiB) and have access to a number of resources and training modules [13]. Our research provides insights into the full range of responses towards biosecurity accreditation that can inform the growth of the Plant Healthy scheme and the development of similar voluntary plant health schemes worldwide. Our focus is on understanding the appetite amongst nurseries and their consumers for accreditation in the UK plant nursery trade to stem the increasing number of 
pest and pathogen introductions. Many of the nurseries operate as private businesses and as such their interest and openness to an accreditation scheme in the sector may ultimately depend on consumer demand and costs involved.

We recently explored whether the gardening public would be receptive to a biosecurity accreditation scheme in the nursery sector and there was wholescale support in principle although less willingness to pay more for accredited products [29]. Here, we will identify where there is support for an accreditation scheme within the nursery sector that grow, purchase and trade large volumes of plants. To assist our analysis, we use a conceptual framework that seeks to capture nursery perceptions of their capability, opportunity and motivation to improve biosecurity behaviours. In the context of improving plant biosecurity through an accreditation scheme, the COM-B [Capability, Opportunity, Motivation-Behaviour] framework (see Section 2) facilitates the examination of the opportunities and challenges raised by nurseries and two key consumer groups. The aim is for this research to inform the future development of planned interventions linked to voluntary plant health accreditation schemes.

\section{Materials and Methods}

The COM-B framework (Figure 1) [30,31], originally developed in the field of public health, focuses on how to design behaviour change interventions.

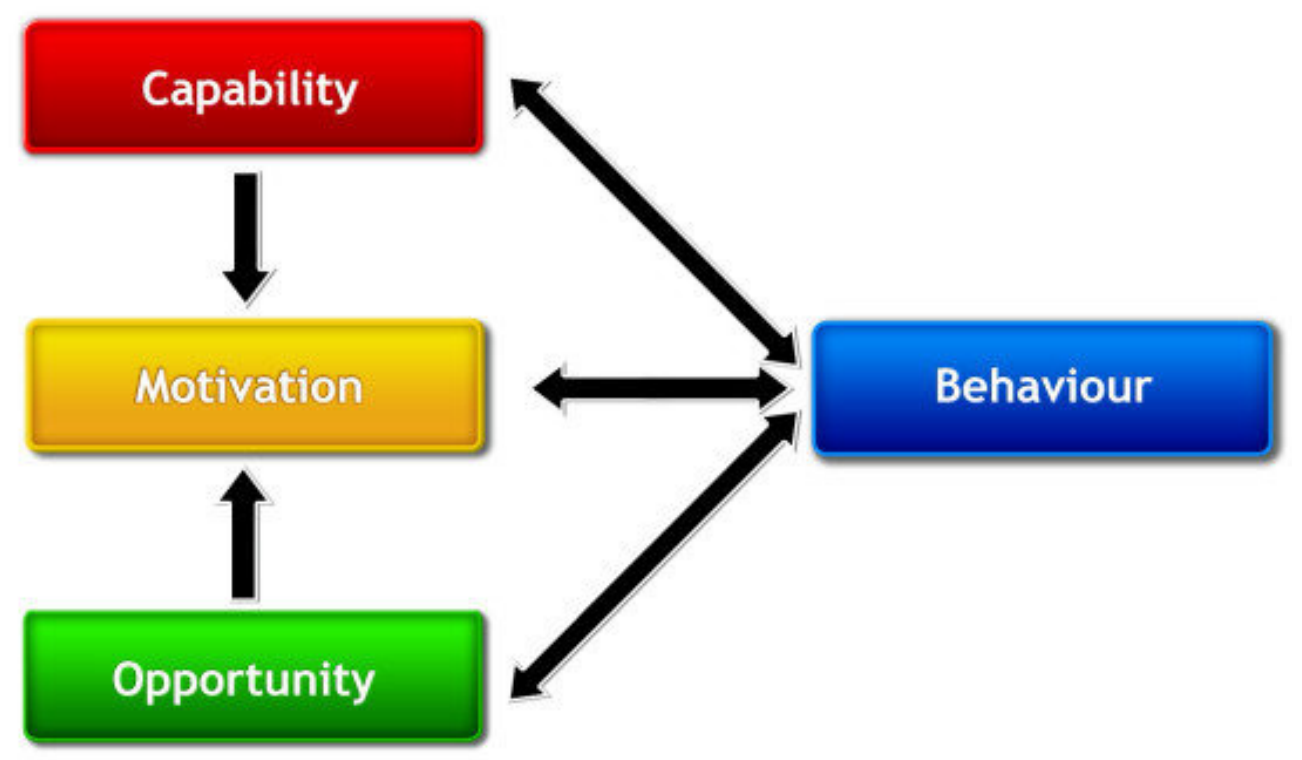

Figure 1. The COM-B framework (Michie et al., 2011).

Michie et al. [30,31] emphasise that it is necessary to assess the types of behaviours that are required before designing any scheme to make changes. Capability includes individual physical and psychological capacity; Opportunity explores the external social, economic and physical environment that can facilitate or negate required behaviours; Motivation to enact the required behaviours involves reflective decision-making processes and automatic (emotional) processes. Michie et al. [30,31] further break down the three components to include sub-elements: Physical and Psychological capability (e.g., tools, insights, knowledge and skills to carry out the behaviours); Physical and Social opportunity (e.g., social networks or physical environment); Reflective and Automatic motivation (e.g., habit, emotion, beliefs). Using the COM-B framework allows us to reflect on key components that are likely to influence greater involvement of the nursery sector in an accreditation scheme.

The research presented in this paper was based on the collection of qualitative data between 2017 and 2019 as part of the PHYTO-THREATS project [32]. Data presented here were derived from semi-structured interviews with three groups of stakeholders: (Group 1) 
Nursery owners/managers; (Group 2) Local Authority staff who have responsibility for arboricultural activities (e.g., tree and arboriculture officers); (Group 3) Representatives of the retail sector responsible for plants. These included two lifestyle brands with multiple stores, two garden centres with multiple stores, one online plant retailer, one buyer for a specific large retailer with multiple stores and one plant consultant working for several retailers. Group 1 interviews $(n=19)$ were mostly carried out face-to-face at the nursery. Five of the nurseries involved focused on forest/woodland trees whilst the rest provided plants for landscaping/amenity. The nurseries varied in size from small (0.8 ha) to large (196 ha) with annual turnover ranging from $£ 40,000$ to $£ 11$ million. Interviews for group 2 (Local Authorities $n=15$ ) and group 3 (retailers $n=7$ ) were conducted exclusively over the phone. Recruitment for each of the stakeholder groups was purposeful and based largely on recommendations, introductions from colleagues and existing contacts. Most of the group 3 retail participants were recruited after the lead author presented the research at an industry meeting in 2018. Questions across the three groups focused on interviewee role and responsibilities regarding tree and plant health and included type of business; pest and disease awareness and information sources; biosecurity practices; and attitudes towards an accreditation scheme (capability, motivation, opportunity). We used Parke and Grünwald [33] and Parke et al. [34] to identify a range of on-site biosecurity practices that would likely be necessary to achieve accreditation. These included the use of (i) Raised benches/gravels beds to keep containers off the ground; (ii) Evidence of puddles indicating insufficient drainage; (iii) Vehicle washing station; (iv) Boot washing station/disinfectant mat; (v) Washing station for plant pots and tools; (vi) Regular removal of weeds and leaf debris; (vii) Water sources (ideally mains or treated water); (viii) Use of trusted sources for supply (i.e., sources with strict biosecurity practices); (ix) Using plants grown within the UK from UK propagation materials (seeds/cuttings, etc). The launch of the PHYTO-THREATS project in the UK in 2016 coincided with the early development of what is now the Plant Healthy Certification Scheme [13]. While the authors were fully cognizant of progress and several of our nursery respondents were involved in piloting the scheme, our interview questions focused entirely on a hypothetical plant health accreditation scheme as a means of understanding motivations and challenges to becoming involved.

Informed consent was given by interviewees and all of the interviews were digitally recorded. The audio files were transcribed by a professional transcription service and subsequently checked for accuracy. Coding of the qualitative data for groups 1 and 3 was carried out by the lead author whilst group two interviews were carried out and coded by a colleague (see acknowledgements). All coding was carried out using Nvivo. Codes are a useful way to develop categories and group responses when exploring descriptive data $[35,36]$. The data were initially examined by two of the authors to scope out initial framings and themes followed by an open coding approach [36] which facilitated the development of coding categories. The coding categories then allowed us to highlight key themes relevant to attitudes towards accreditation (Table 1). Quotes are anonymised but labelled with respondent type and number.

Table 1. Key themes on nursery attitudes towards accreditation.

\begin{tabular}{llll}
\hline & Capability & Opportunity & Motivation \\
\hline \multirow{3}{*}{ Themes } & $\begin{array}{l}\text { Extent of current biosecurity } \\
\text { practices on-site and off-site }\end{array}$ & Current memberships of schemes & Costs of implementing measures \\
\cline { 2 - 4 } & $\begin{array}{l}\text { Capacity for biosecurity } \\
\text { improvements }\end{array}$ & Plant health policy environment & Collective support or safety net \\
\cline { 2 - 4 } & & Knowledge sharing amongst members & Consumer demand \\
\cline { 2 - 4 } & Fit with current values and business objectives & \\
\hline
\end{tabular}




\section{Results}

As plant pests and diseases and their impacts on the environment and food security has moved up the political agenda, the pressure on growers and nurseries to ensure they are producing and selling biosecure products has increased. For example, one large nursery we spoke to raised concerns about the level of risk and financial burden on nurseries should there be an outbreak onsite or related to their planting stock. The manager felt that other businesses in the horticulture sector such as retailers of plants and in landscaping faced lesser risks as they would be able to seek compensation from nurseries for any infected plants they had purchased. Thus, good biosecurity practices are considered paramount in the nursery sector. Research findings are presented using the three components of the COM-B framework $[30,31]$ that are likely to inform nursery perspectives and behaviours in the context of joining a voluntary accreditation scheme. While we have attempted to frame our findings within the categories of capability, opportunity and motivation they are not mutually exclusive and often overlap e.g., consumer demand could be seen as both an opportunity and motivation.

\subsection{Capability in the Context of Biosecurity Practices}

Capability can include both physical and psychological capacity. In the context of nurseries and their ability to meet biosecurity standards necessary for an accreditation scheme, capability can refer to their knowledge and skills and the ability to physically implement changes on-site and off-site. Nursery participants highlighted the key challenges they faced in implementing a suite of biosecurity practices (see Table 2) and we select several examples that illustrate perceived capability including inspections, quarantine, waste disposal and use of trusted sources for supply.

Table 2. Capability challenges in relation to biosecurity practices.

\begin{tabular}{|c|c|c|c|}
\hline Biosecurity Measure & $\begin{array}{c}\text { Benefits of } \\
\text { Biosecurity Measure }\end{array}$ & $\begin{array}{c}\text { Number of Nurseries That } \\
\text { Have Implemented } \\
\text { This Practice }\end{array}$ & Capability Challenges Raised by Nurseries \\
\hline $\begin{array}{l}\text { Containerised plants } \\
\text { grown on raised } \\
\text { benches/gravels beds }\end{array}$ & $\begin{array}{l}\text { Avoids contact with } \\
\text { potentially infected water and } \\
\text { soil, and splash dispersal of } \\
\text { inoculum in soil }\end{array}$ & $\begin{array}{l}11 \text { (though depends on the } \\
\text { type of plant and location) }\end{array}$ & $\begin{array}{l}\text { Difficult to manage the turnover of different } \\
\text { size plants and their requirements } \\
\text { - } \\
\text { Difficult to put trees on raised benches } \\
\text { - } \quad \text { Wind blow if raised benches outdoors } \\
\text { - } \\
\text { Paised benches can be costly } \\
\text { separate from the soil }\end{array}$ \\
\hline Vehicle washing station & $\begin{array}{l}\text { Ensures that vehicles entering } \\
\text { or moving around a site are } \\
\text { clean and free of any } \\
\text { potential pathogens }\end{array}$ & 2 & $\begin{array}{l}\text { - It is not realistic to keep washing vehicles } \\
\text { - } \quad \text { Difficult to manage/police washing regimes } \\
\text { - } \quad \text { There are no/few vehicles that come onsite } \\
\text { - } \quad \text { It would be costly to have a washing station } \\
\text { - } \quad \text { No customer demand for biosecurity to } \\
\text { justify costs } \\
\text { Washing would create puddles and } \\
\text { - } \quad \text { It is better to focus on ensuring plants } \\
\text { - } \quad \text { Not healthy } \\
\text { Not considered this option }\end{array}$ \\
\hline $\begin{array}{l}\text { Boot washing } \\
\text { station/disinfectant mat }\end{array}$ & $\begin{array}{l}\text { Ensures that individuals do } \\
\text { not introduce pathogens } \\
\text { picked up from other areas }\end{array}$ & 8 & $\begin{array}{l}\text { - } \quad \text { Tried it and was difficult to manage } \\
\text { - } \quad \text { Nifficult to manage/police washing regime } \\
\text { this action } \\
\text { - Nursery close to public footpaths and } \\
\text { accessible to wild animals who will not be } \\
\text { participating in action so a waste of time } \\
\text { Not considered this option }\end{array}$ \\
\hline
\end{tabular}


Table 2. Cont.

\begin{tabular}{|c|c|c|c|}
\hline Biosecurity Measure & $\begin{array}{c}\text { Benefits of } \\
\text { Biosecurity Measure }\end{array}$ & $\begin{array}{l}\text { Number of Nurseries That } \\
\text { Have Implemented } \\
\text { This Practice * }\end{array}$ & Capability Challenges Raised by Nurseries \\
\hline $\begin{array}{l}\text { Washing station for plant } \\
\text { pots and tools }\end{array}$ & $\begin{array}{l}\text { For disinfestation of } \\
\text { potentially infected } \\
\text { onsite materials }\end{array}$ & $\begin{array}{l}12 \text { ( } 5 \text { of these specified } \\
\text { tools only) } \\
\text { Generally, no specific } \\
\text { washing station. }\end{array}$ & $\begin{array}{l}\text { - } \quad \text { Don't use/re-use pots } \\
\text { - } \quad \text { All pots leave with the customer } \\
\text { - } \quad \text { Chem't feel it is necessary } \\
\text { contamination cleaners cause environmental }\end{array}$ \\
\hline $\begin{array}{l}\text { Regular removal of } \\
\text { weeds and leaf debris }\end{array}$ & $\begin{array}{l}\text { Removes unwanted plants } \\
\text { that can also act as hosts for } \\
\text { Phytophthora and other pests } \\
\text { and pathogens }\end{array}$ & 14 & $\begin{array}{l}\text { Difficult to manage with restricted availability } \\
\text { of herbicides } \\
\text { Too costly and time-intensive to tidy areas } \\
\text { surrounded by trees }\end{array}$ \\
\hline $\begin{array}{l}\text { Water sources (ideally } \\
\text { mains or treated water) }\end{array}$ & $\begin{array}{l}\text { Mains or boreholes tend to be } \\
\text { at a lower risk of pathogen } \\
\text { contamination but other } \\
\text { sources such as reservoir } \\
\text { ponds, rainfall butts or } \\
\text { extracting from rivers carry } \\
\text { higher risk unless treated }\end{array}$ & $\begin{array}{l}\text { Borehole } 7 \\
\text { Mains } 7 \\
\text { Rainwater } 5 \\
\text { Pond/reservoir } 7 \\
\text { River } 3 \\
\text { Spingwater } 1 \\
\text { Canal } 1 \\
\text { Drainage water } 2\end{array}$ & $\begin{array}{l}\text { - } \quad \text { Limited by site type and options } \\
\text { - New systems are costly }\end{array}$ \\
\hline $\begin{array}{l}\text { Reduce puddles and } \\
\text { excess run-off }\end{array}$ & $\begin{array}{l}\text { Excess water can spread } \\
\text { water-borne pathogens }\end{array}$ & 8 & $\begin{array}{l}\text { Costs and time involved in installing better } \\
\text { drainage } \\
\text { Improving drainage difficult when site is in } \\
\text { constant use } \\
\text { - } \quad \text { Keeping on top of foot and field traffic } \\
\text { compacting raised areas } \\
\text { - Nursery sites on slopes with run-off } \\
\text { Nursery located on natural springs }\end{array}$ \\
\hline $\begin{array}{l}\text { Using plants grown } \\
\text { within the UK from UK } \\
\text { propagation materials } \\
\text { (seeds/cuttings etc). }\end{array}$ & $\begin{array}{l}\text { Reduces/eliminates risk of } \\
\text { introducing pests and } \\
\text { pathogens not yet present in } \\
\text { the UK }\end{array}$ & All & $\begin{array}{l}\text { - UK Climate means slower growth } \\
\text { - Not always feasible due to volumes and type } \\
\text { of plants } \\
\text { - } \quad \text { UK plants more costly } \\
\text { Resources needed to learn to grow plants not } \\
\text { grown before }\end{array}$ \\
\hline $\begin{array}{l}\text { Regular inspection of } \\
\text { plants by a staff member } \\
\text { with plant health training }\end{array}$ & $\begin{array}{l}\text { Allows rapid action to deal } \\
\text { with pest and disease threats, } \\
\text { raises awareness of common } \\
\text { health problems onsite and } \\
\text { quick identification of new } \\
\text { health problems arising }\end{array}$ & All & $\begin{array}{l}\text { Knowledge and resources to do in-depth } \\
\text { inspections and testing } \\
\text { Might not know the history of the plant or } \\
\text { whether a masking agent has been used } \\
\text { - } \quad \text { Volumes too high to check all plants } \\
\text { - No qualifications for staff on plant health } \\
\text { How to see the unseen }\end{array}$ \\
\hline $\begin{array}{l}\text { Quarantine and regular } \\
\text { inspection of plants } \\
\text { brought in from } \\
\text { elsewhere in a location } \\
\text { well away from existing } \\
\text { nursery stock }\end{array}$ & $\begin{array}{l}\text { Allows rapid action to deal } \\
\text { with pests and pathogens that } \\
\text { might be introduced from } \\
\text { other locations and prevents } \\
\text { transfer to existing stock }\end{array}$ & $\begin{array}{l}\text { Varies. Sickly plants } \\
\text { separated. Some have a } \\
\text { separate area for imports }\end{array}$ & $\begin{array}{l}\text { - Holding stock costs money } \\
\text { - } \quad \text { Lack of space } \\
\text { - } \quad \text { No guidance on what constitutes length of } \\
\text { time for quarantine } \\
\text { - Holding rather than disposing is keeping } \\
\text { disease on site } \\
\text { Difficult to manage the watering/management } \\
\text { requirements of mixed plants in one } \\
\text { quarantine area }\end{array}$ \\
\hline $\begin{array}{l}\text { Disposal of waste: dead, } \\
\text { dying or unwanted } \\
\text { plant material }\end{array}$ & $\begin{array}{l}\text { Disposing of plants close to } \\
\text { nurseries carries a high risk of } \\
\text { pest proliferation. Disposal } \\
\text { should be through a } \\
\text { contained composting system. }\end{array}$ & $\begin{array}{l}\text { Burning }=10 \\
\text { Composting }=8 \\
\text { Bury }=3 \\
\text { Landfill }=1\end{array}$ & - No clear guidance on what to do with waste \\
\hline
\end{tabular}


Table 2. Cont.

\begin{tabular}{|c|c|c|c|}
\hline Biosecurity Measure & $\begin{array}{c}\text { Benefits of } \\
\text { Biosecurity Measure }\end{array}$ & $\begin{array}{c}\text { Number of Nurseries That } \\
\text { Have Implemented } \\
\text { This Practice* }\end{array}$ & Capability Challenges Raised by Nurseries \\
\hline $\begin{array}{l}\text { Use of trusted sources for } \\
\text { supply (i.e., sources with } \\
\text { strict biosecurity } \\
\text { practices) }\end{array}$ & $\begin{array}{l}\text { Important to assess whether } \\
\text { the plant health policies and } \\
\text { procedures are fit for purpose }\end{array}$ & All who import & $\begin{array}{l}\text { - Trusted suppliers that can provide the volumes } \\
\text { \& plant demands of nursery customers } \\
\text { - Challenges with checking their } \\
\text { - } \quad \text { Exactices continuously } \\
\text { Experience needed to identify good practices }\end{array}$ \\
\hline
\end{tabular}

* Nurseries may choose more than one action.

\subsubsection{Inspection of Plants}

All nurseries interviewed conducted some form of inspection of plants on arrival at their sites to look for obvious signs of ill health. The challenges with the plant trade lie in what can't be seen through visual inspection and several nurseries highlighted the difficulties of spotting risky plants with hidden symptoms requiring knowledge, skills and technological solutions:

"Where we have plants arriving from trade, we have a good strong team ... trying to identify any particular issues with it, but we are more exposed, undoubtedly in that area ... You don't know whether some masking agent or whatever it may well be, has been used of late, which has enabled it to come in ... " (Nur_5)

"I' $m$ sure every nursery does the same. We look at the plants when they arrive and we look at them whilst they're still with us very carefully, but the trouble is we don't know what we're looking for. We are looking for obvious things that stick out like a sore thumb ... normally they come to us when they are in a dormant state. There's no leaves on it so the trees looks visually perfectly okay but in reality, it isn't." (Nur_3)

\subsubsection{Quarantine}

Setting up a quarantine area in nurseries for imported plants was also seen as challenging. Most plants will be quickly moved on to their final destination although trees may get potted on if they don't sell. In certain circumstances, suspicious plants may be isolated but few nurseries had a formal quarantine area as space is often an issue. Most questioned the cost-effectiveness of quarantining with wide-ranging assumptions on the required length of time:

"The other problem is if you've got herbaceous type plants, how can you quarantine that for whatever period of time? They have to come in as a liner or as a finished plant. You can't keep the herbaceous plant for 12 months, that would be a compost heap. You can't do it ..." (Nur_3)

"It's not like we've got this endless gap of sales opportunity, for a plant called class B, it goes now or it never goes. So, you can't hold it in quarantine for three or four months ... because you haven't got a marketplace after that" (Nur_5)

\subsubsection{Disposal of Waste}

Managers felt there was no clear guidance or industry standard on good practice for dealing with dead and dying plants. Composting was normal if the plant was believed to have died from 'natural' causes. If plants were suspected of having a disease, the common agreement was to get rid of them as quickly as possible. Plant health inspectors were contacted for suspicious cases and the two main approaches were to bury or burn. Both options carry potential environmental implications and lack of clarity on which approach to take was considered less than satisfactory whilst recognising that:

"the whole horticulture industry has got a massive issue on what it does with its waste"

(Nur_13) 


\subsubsection{Use of Trusted Sources for Supply}

An important component of plant health off-site is ensuring the supply chain is biosecure. Our sample involved a mixture of nurseries growing their own plants on-site but also importing stock from elsewhere largely due to climate, the time required to grow certain plants and ongoing consumer demands for specific plants and volumes. One biosecurity management solution is to only purchase products that are UK grown and most nurseries indicated they will buy British stock where possible. However, nurseries cited challenges with the 'home grown' concept. One nursery highlighted the costs and time frame for growing certain popular plants could prove prohibitive for many nurseries in the UK:

"A lot of folk talk about how they'll just buy British but their ability to do that is so limited by the actual nurseries that grow. You can't get a $20 \mathrm{ft}$ conifer grown in the UK ... it just doesn't happen ... I mean you can get big Photinias from Italy that are maybe four years old which would have taken 20-30 years here to grow and of course, going to be considerably cheaper. Nobody's going to grow one here for 30 years and equally, the public's not going to want to pay the 30-year money". (Nur_10)

Overall, in relation to the suite of biosecurity practices presented to nurseries, the most common issues were related to cost, working with the existing topography and infrastructure of current sites, relevance of the practice if there is no demand for biosecurity, and accessing or interpreting biosecurity guidance.

\subsection{Perceived Opportunity for Better Biosecurity}

Opportunity in the COM-B model refers to external factors which can facilitate better biosecurity behaviours. Opportunity is comprised of two key components: the physical such as the right timing and political environment and the social which encompasses social norms and cues. Our exploration of attitudes towards a hypothetical biosecurity accreditation scheme highlighted the perceived opportunities and challenges presented by nurseries. There was support for a biosecurity accreditation scheme, particularly in the current political climate where there is a strong focus on plant biosecurity in the nursery sector. Heightened concerns about the possible introduction of Xylella fastidiosa and the devastating impacts that this bacterial pathogen could have on a multitude of hosts has galvanised sector fears around the import trade.

However, plant health awareness has been increasing for some time and several nurseries, particularly those dealing with trees have significantly reduced or stopped importing:

"Well, plant health I would say over the last four or five years has moved up the agenda, not only in terms of each individual nursery and businesses but right across the whole of the horticultural industry and certainly in the nursery business" (Nur_3)

"Well, we no longer buy any stock at all from outside the UK, so that was a decision we made last year finally. We used to buy in perhaps a couple of hundred thousand trees from various parts of Europe prior to that, so we don't do that anymore. We try and grow as much as we can ourselves on site from seed and that's reckoned to be relatively secure." (Nur_9)

Not all nurseries can take this approach and so one of the ways in which opportunities can be intensified is through securing the supply chain. Most participants talked about building trusting relationships with suppliers over the years which involves repeated visits, keeping the supply chain short and focussing on trading with nurseries that have the same values. Reputation for quality, evidence of good practice, trust and traceability were considered to be key attributes:

"We obviously keep our numbers of suppliers down very, very low to minimise our exposure and what you have to manage. We only choose grower suppliers rather than traders ... It means what you buy comes from where it comes from as opposed to somebody who's buying plants from a third party and trading it on so it cuts down links in the chain ..." (Nur_18) 
"We buy from the nurseries that we know, we trust and we've been dealing with for a number of years." (Nur_3)

"[We] are third generation nurserymen so we've got suppliers who our fathers and grandfathers dealt with. So, you can't get much longer term than that. All of them plant passported, many of them over 100 years old and people we're confident they're also monitoring their own sub-suppliers as well. Chain of command and traceability right to the beginning." (Nur_4)

Another opportunity but also challenge relates to the expansion of, and increasing engagement with, plant health inspectors whose specific expertise and advice were seen as a particularly important resource for nurseries. However, there were concerns that inspections did not take place at all points of entry and establishment, or with all those who may import plants. There was a perceived lack of fairness with one nursery manager highlighting, "I'd quite like to have more [inspections] but equally, I'd like everybody else to have more. I don't want to be the only one getting more inspections, I want us all to get it" (Nur_10). Others argued that the government should be taking a stronger regulatory role to avoid the dangers of the 'weakest link'.

Participants identified a desire for access to knowledge sharing and collective support that could be provided by an accreditation scheme including greater connectivity and being able to assess the practices of suppliers. We first explored whether there were opportunities to build on existing experiences of scheme memberships. Investors in People and the Horticultural Trade Association's (HTA) Ornamental Horticulture Assurance Standard (OHAS), formally known as BOPP (British Ornamental Plant Producer's certification scheme), were UK-based initiatives most often mentioned but neither of them focuses exclusively on plant biosecurity and few of our participants were current members. Feedback from some of our participants indicated that membership schemes could potentially end up as a 'tick box' exercise where members might join the scheme but undermine the resilience of the system by not fully participating in raising standards:

"We don't want the assurance scheme to become a hiding scheme and we don't want the assurance scheme to become just that nice to have thing that you tick a box with ..." (Nur_5)

As one participant highlighted, there were concerns about whether changing their own behaviours would be enough to avoid a biosecurity incident if others were not doing the same:

"I think what worries me the most is what other people are not doing because other businesses near us could do something wrong ... I have no problem paying for it [accreditation] as long as everybody does and it's proportionate to the size of the business." (Nur_7)

Similarly, there was some apprehension about taking costly steps to improve biosecurity if others did not follow suit:

"... If we're all doing it, it's a level playing field, and we all benefit from it. We all benefit from the extra plant health, we all benefit from the quality assurance. If we're getting a little bit more for our plants, which we would have to, because there are extra costs involved, then so be it. But I couldn't afford to raise my costs and be the only one that's doing it ..." (Nur_2)

Thus, nurseries were keen that an accreditation scheme should include all nurseries as well as other actors involved in the plant supply chain. Managers emphasised the necessity of cooperation amongst nurseries with several highlighting the need for the scheme to be compulsory:

"I mean I wouldn't bother if it's not compulsory for everybody else to do it ... if we follow all the rules and do all the checking and do all the training and then a nursery next door to us or a landscape contractor or a garden centre operator within 10 miles or 
$10 \mathrm{~km}$ of us don't care about any of this and Xylella is found there, we will be shut down as well so what is the point of us doing it?" (Nur_3)

The belief that an accreditation scheme should be compulsory was not shared by everyone and there was recognition that smaller businesses need support if the standards required for an accreditation scheme are to become mainstream. As well as acknowledging the potential difficulties of adapting a scheme to facilitate the inclusion of nurseries of all sizes, there was widespread agreement that to be effective a scheme should extend to all that are involved in the specification, supply and purchasing of plants. Other actors identified included landscape contractors and large non-specialist retailers. Home production appeared to be an established protocol for tree nurseries as evidenced above. However, there are 'shades of grey' whilst trying to maintain a strong biosecurity regime as highlighted by this tree nursery:

"We've taken the attitude that no matter what you do, with all the legislation and checks and everything, no system's perfect. So, therefore we don't import. After that, our next choice if we do have to buy anything at our customers' request, then we will attempt to buy from another nursery that doesn't import. But that's pretty difficult, so the third choice is we'll buy from a nursery who can prove to us that they have reasonable quarantine measures... If that's not possible, we then try and get the plants and they would not come here [on site]." (Nur_13)

Our exploration of attitudes towards accreditation focussed on the hypothetical rather than an identified scheme but there were still concerns about what would be required and a wariness about whether the 'rules' of membership would fit current business objectives and values. Two nurseries reflected on whether membership would provide added value to their current practices:

"You mustn't swop accreditation effort and cost for actually good practice because ... if you say your budget for plant health is $£ 10,000$, it would be terrible to spend $£ 3000$ in accreditation, $£ 7000$ on plant health when you could do $£ 10,000$ on plant health and no accreditation." (Nur_18)

"If we think we're doing as much as any assurance scheme anyway, then why would we join in an assurance scheme to say we're doing it when we know we are ... unless the customer says ..." (Nur_5)

Other nurseries shared their trepidation at joining a scheme that might require them to change practices they are currently happy with even though there may be recognisable advantages:

"On the one hand you might learn something and get some tips and that's good. The flipside to that is ... you can possibly hear the same thing for the 20th time and it's something that's very difficult or expensive to do." (Nur_1)

"As an independent business, we do things our own way because it suits our time schedule. So, I wouldn't want to change things that made things more stressful for us having to abide by a certain set of rules. We know how things work here, and I believe that we keep this place pretty pest and disease free as we can, and we haven't had any major issues..." (Nur_19)

For an accreditation scheme to be taken seriously, all participants agreed that it should be enforceable. Several other queries were also raised that related mostly to who should be involved in an accreditation scheme, what is involved and how such a scheme would be policed. The approach, suggested by most participants, could be to provide warnings and guidance for those members that are not meeting the required standards. This could then be followed by expulsion from the scheme for repeated transgressions as highlighted by two nurseries:

"... if you're part of a scheme and then you don't meet the requirements for it, then you should have the membership of that scheme terminated ultimately." (Nur_17) 
"Well, I've heard two schools of thought, one is just kind of gently nudge them in the right direction, in a sense, which is probably the first thing you should do, but ... it would probably be nice to see a blacklist eventually ... That might be the biggest kind of stick in many ways to change their attitudes." (Nur_9)

However, other participants wondered whether the expulsion of members-rather than providing more support-might also weaken the scheme, especially if key motivators such as nursery buy-in and consumer demand are lacking:

"If we were there and we got hit by a fine we'd be like, 'See you later', and I imagine most other people would as well. There's not enough public support behind any kind of scheme to make it detrimental to leave. You might win a wee bit because you can put it in your advertising but the actual quantifiable amount of money you may or may not lose is pretty slim..." (Nur_10)

\subsection{Nursery Motivations to Join an Accreditation Scheme}

Within the COM-B model, motivations are made up of automatic (e.g., emotional responses) and reflective (e.g., evaluation of experiences) components that influence decisionmaking and behaviours. Within this study, we explored potential motivators and demotivators to participate in an accreditation scheme with a specific focus on costs, collective support and consumer demand. The costs associated with membership and raising biosecurity standards generally was a concern, especially in relation to smaller nurseries. The challenge of an accreditation scheme is that it should span a range of businesses regardless of size, but the physical costs involved in achieving biosecurity standards may be prohibitive:

"So there would be a cost and that is where the problem is and a nursery like ours probably can afford to set aside $£ 30,000$ or $£ 40,000, £ 50,000$ for that, but a small nursery of one or two people, they can't afford it and that's where the dilemma is. If those people can't afford it and we say, "Well, they can't afford it, let's let them just not bother," then the whole biosecurity concept is a meaningless exercise." (Nur_3)

"I think if it became an accepted scheme and you were a large nursery, I think that would be expected of you, but I think for somewhere of our size, I would be surprised if a lot of places like us would join a scheme like that." (Nur_17)

Nevertheless, several nurseries emphasised the benefits of a scheme, particularly if it provided a safety net for its members:

"The other real bonus would be if you were signed up to an accreditation scheme and something like Xylella was in your area and if you got almost like a pardon or you got a different set of consequences than if you were somebody who was not signed up to an accreditation scheme. That's ... very attractive." (Nur_1)

An accreditation scheme that has plant health as its prime focus could also offer more support by improving knowledge sharing and acting as a forum for collective transparency on biosecurity and recognition:

"The benefits would be the information-sharing within that community ... and it would just be good to have recognition for what we're doing and hopefully people see that. They see the accreditation and they think okay these are trusted, they're doing the best they can, we'll buy from them." (Nur_15)

"... when we go out there to buy stuff from somebody else then we should have a better idea of what their practices are and hopefully what they do supply is likely to be more healthy potentially. That's our big issue more than anything else." (Nur_9)

As well as industry recognition, one of the key motivating factors was the perceived level of client or consumer demand for accreditation. Biosecurity considerations appeared more prominent amongst customers of tree nurseries, driven by increased awareness of the risks following the devastating impact of pests or pathogens such as ash dieback, Dothistroma needle blight (often known as red band needle blight) and Phytophthora ramorum. 
"Most people are getting more interested in it now. Our customers became more interested in it obviously because of the Ash disease and red band needle blight ... our customers are aware of phytophthora in larches and sudden oak deaths. So, it's important to us now, for our customers to have confidence that we are disease free." (Nur_13)

However, other nurseries had experienced little if any queries from their customers on biosecurity and this seemed particularly prevalent for ornamental horticulture. A key challenge identified by nurseries was that although some consumers may be more aware of plant health, they still wanted to be able to select and receive plants in short time frames that could necessitate importation:

"Yeah, I think the customers are certainly more interested, they're learning a lot more about it ... it's just educating the customer so they're knowing what's happening, the knock-on effect of this is that there could be delays in getting their stock into them ... it's the whole Amazon effect, they want it overnight sometimes ... " (Nur_7)

Participants also pointed out that different customers will have a different awareness of, and opinions on, accreditation for plant biosecurity and its importance:

"I think our commercial clients, our professional clients would appreciate what we're doing. I think the general public probably don't know a huge amount about what's going on." (Nur_4)

"I think my customers, that is to say independent garden centres, would respond to it with complete apathy." (Nur_6)

In this context, it was important to explore consumer perspectives on the benefits and challenges of procuring plants through accredited sources. We focussed on Local Authorities and large 'multiple' retailers. These types of commercial consumers are particularly interesting because they both typically purchase large volumes of plant products, but the biosecurity risks are different. Local Authorities face plant health threats from landscaping in public spaces and the wider environment whilst large retailers face biosecurity threats presented by the importation of ornamental plants that are sold in their stores. Large-scale retailers are a highly influential sector that can not only shape consumer plant purchasing preferences in-store and online but also have purchasing power through the volume and scale of plants procured through selected suppliers. Both types of consumers could potentially have an influential role in driving nursery motivations for joining an accreditation scheme, specifically through future decision-making on their biosecurity requirements.

\subsection{Consumer Perspectives}

Our research with the Local Authority and large retailer stakeholders identified the complexities of different consumer requirements which will impact on support (or not) for accredited nurseries. There was considerable support amongst Local Authority participants for nursery suppliers to be part of an accreditation scheme and four specifically stated that they would pay more for accredited plants. A key benefit was thought to be the availability of a unifying standard that could meet biosecurity requirements and reduce the need to interpret varying protocols of different suppliers. As the participants below highlighted, membership of an accreditation scheme would provide an established level of confidence that the plants being supplied were biosecure and that there were established standards:

"If there was a scheme, I would be more likely to buy trees from somebody proving that they were doing due diligence." (LA_12)

"I think it would be very useful, you know, if it was a way of providing some assurances as a client or as someone that's been supplied nursery stock for projects and schemes. If they were to have that extra confidence in where the stock is coming from, and the quality of the stock, and it's free from potential pests and diseases, that would be useful." (LA_1)

"I think nurseries produce their own statements on biosecurity ... I think that's difficult for people trying to interpret these various different statements on biosecurity, so I do feel like there needs to be a standard on it." (LA_8) 
However, one participant raised the question of whether an accreditation scheme was needed believing that biosecurity practices should be intrinsic to any nursery operation, reflecting regulations and controls already in place.

Large retailers provided a similar response given that the demand for plant biosecurity from their consumers (general public) is lacking and there was scepticism about whether consumers would accept biosecurity practices such as removal of high-risk plants from sale or higher costs. Our respondents felt that conversations about biosecurity will likely happen away from the shop floor as there is a consumer expectation that plants for sale are pest and disease-free.

"I think if you asked most of our customers, they would just be expecting us to be doing the right thing and not exposing their gardens, their hobby, their passion to the darker side of life .... I think it's part of your pledge as a retailer." (Retail_4)

"So much of what we're dealing with [in] plant health, they're either not interested in or don't understand or don't need to know. So, we would probably be quite careful about what we were saying to the customer and decide whether we actually needed to say anything. I think with a lot of these things, it's best ... just to do the right thing without telling them, a bit like the food industry. They're not writing "E-coli free" on their lettuce but you just assume that it will be". (Retail_2)

Furthermore, the retailers we spoke to had already established what they believed to be safe operating practices where plant products continue to be sourced overseas and were keen to emphasise the high level of traceability so that any plant health problems can be traced to the source and remediated:

"Traceability is important, so at any stage in the process to be able to say, 'Right, this batch of plants, the cuttings came from here, this delivery to this wholesaler was from here from this area of the nursery on this date', and so on. The better the record-keeping as well, it all maintains that discipline and traceability and then if there is an issue it makes it that much easier to isolate where the problem came from. And that's really effective too in being able to control any kind of plant health problem". (Retail_7)

Both sets of respondents echoed nursery practitioner concerns about who should be involved in an accreditation scheme and how accountability will be monitored. For accreditation to work, Local Authority participants felt that all nurseries needed to be signed up to the scheme:

"Otherwise you would find yourself in a difficult position, if you were stipulating they must have this accreditation. ... we wouldn't want to ask for something that we know that only 50\% of the nurseries out there have." (LA_1)

In a similar vein, Local Authority respondents believed that an accreditation scheme should cover more than just nurseries including overseas suppliers and other sectors in the UK:

"There are nurseries which are doing the right thing and saying we're being transparent on this, and this is the measures we've got in place. But then you could have a development site and a landscape architect who's just gone and procured X number of trees for the site, and it's just come in from wherever. Yes, it [pest or disease] might have been picked up at the ferry terminal or port, but it may not have been picked up. That's the issue, isn't it?" (LA_11)

One retailer asked whether international businesses and traders would be included as imported plants represented a high risk for pests and diseases. Another emphasised that responsibility for biosecurity can differ according to who is involved in the supply chain and questioned where responsibility for biosecurity and accreditation would lie.

A further echoing of nursery concerns related to the standards associated with membership of an accreditation scheme. It was pointed out that a scheme is only valid if members actually implement biosecurity practices and much would rest on how a scheme is audited. It was felt that a scheme would need to be enforceable following a 'carrot and 
stick' approach with encouragement via education and financial penalties for infringements. One retail respondent emphasised the measures that needed to be in place for members who did not comply with the required standards whilst another was sceptical about whether standards would be maintained throughout the year:

"... I think if it's a join and everyone passes, everyone would join. It only has teeth if you get thrown out and you can't operate your business." (Retail_5)

"I think the only drawback will be if it doesn't guarantee or doesn't work... The same with any quality scheme that we deal with in other areas. You can become accredited, it's as good as the day you're audited, it doesn't necessarily mean what you produce is always going to be at that standard." (Retail_2)

In this context, it may be necessary to consider how current practices and relationships could be augmented by a plant accreditation scheme in this sector although respondents agreed that any scheme that would drive up industry standards would be beneficial. This could happen if all major customers specified that accreditation was a requirement.

\section{Discussion}

The trade-in live plants for planting is an extensive and ever-growing industry representing a retail market value of $\$ 225$ billion [1]. A recent study by the International Association of Horticultural Producers [1] acknowledged that the exponential trade growth is associated with a risk of introducing plant pests and diseases. To avoid the reduction or restricted movement of plants that would inevitably impact the future landscape of trading there is a need to improve and increase the visibility of good biosecurity practices within the sector. A voluntary scheme focussed on biosecurity would be one way to achieve this. The COM-B framework [30,31] facilitated exploration of key capabilities, opportunities and motivations of nurseries as well as perceived challenges to joining an industry-wide voluntary accreditation (or equivalent) scheme. If we consider accreditation to be the intervention that would improve biosecurity behaviours, the COM-B framework allowed us to explore what changes are required to facilitate the behaviour change i.e., better biosecurity practices $[30,31]$. The overriding message from our study is that nurseries want to purchase and grow strong, healthy plants.

Discussions around capability highlighted the valuable role of visual inspection but that much can be missed without the right knowledge or tools to detect hidden symptoms. In this context, professional inspections through fully trained and experienced inspectors were considered important but there were concerns about the loopholes that allowed some traders to avoid inspections. Perceived fairness of the inspection system and who is included could impact psychological capability. Similar results were reported by the AIHP [1] following a recent survey of its membership on the value of an industry-wide voluntary plant health standard. They identified concerns around potential costs associated with a scheme and perceived fairness if less visible plant sellers are not included in inspections or adopting control measures. There was also an expressed desire for greater knowledge on biosecurity practices from reliable and trusted sources. Our research identified additional knowledge needs around on-site practices including how to dispose of diseased plants. However, there were also several physical challenges such as how to improve drainage to avoid puddles that can carry Phytophthora pathogens and ensuring that water sources are pathogen-free, particularly where site conditions are difficult to change, and costs could be prohibitive. Preventative measures such as quarantining on-site were perceived to be psychologically (e.g., not cost-effective) and physically (e.g., lack of space) challenging. Growing all plants in the UK was not considered to be economically feasible or physically possible if consumer demands for many plant varieties within certain cost margins are to be met. Trusted supply chains were considered to be more effective. Indeed, the AIHP [1] highlights the benefits of global trade between plant producers within current regulatory frameworks. They suggest that a global scheme promoting a common plant health and biosecurity standard would provide a transparent means of improving the biosecurity protocols of nurseries, increasing confidence in the sector and reducing any risks. 
A voluntary plant health scheme provides both a physical and social opportunity for nurseries to improve and promote their biosecurity practices. In the UK, there has been a growing policy focus on plant health and explicit support for a nursery accreditation or certification scheme to increase biosecurity. The Plant Healthy certification scheme has recently been launched after several years of planning and piloting [13]. The core component of the certification scheme is a plant health management standard (PHMS) which is an amalgamation of a pest risk analysis and the principles of 'Appropriate Levels of Protection' from the World Trade Organisation adapted to a nursery or garden centre site. The standard currently comprises five key categories: Management and responsibilities; Plant health hygiene and housekeeping; Plant health controls; Monitoring and ongoing plant health assessment; Recognition, competence and training. Nurseries are independently audited on an annual basis and receive certification and the right to use the Plant Healthy logo upon passing. The costs of the audit depend on the size of the business. Many of the standards cover the knowledge needs identified by our research such as waste treatment and disposal, water usage and cleaning and sterilisation. However, the challenge remains of how to encourage wider take-up of the scheme and how it will be enforced in practice with operational monitoring in place to ensure compliance. As identified in the AIPH report [1] and our own research, a key motivation for nurseries to sign up to a scheme is if they see that their peers are equally committed. The principles of a successful certification or accreditation scheme highlighted by Curtis et al. [25] suggest membership that is beneficial rather than burdensome and increased credibility were key. Additionally, the required standards need to be seen as feasible and cost-effective as in the case of quarantining requirements which many of our nurseries felt were not possible due to the volumes and shelf life of certain plants. A good relationship with regulation can make schemes more effective $[1,25]$ but consultation with the horticultural sector on the benefits, feasibility and cost-effectiveness of voluntary standards will improve uptake of any scheme and our study provides important insights into the perceived benefits and challenges as identified by UK nurseries.

We identified that key motivations to participate in an accreditation scheme would be (i) the collective support that would come into play in a biosecurity emergency and (ii) consumer demand. We explored the perspectives of two potentially important largescale consumers that cover both the public and private sector and included retail sales and wider landscaping and environmental planting for the public good. The overarching message from these consumers of plants was that an accreditation scheme that increased standards and provided a measure of good biosecurity would be considered a bonus, but more information would be needed before membership of a scheme became a condition of supply. As with nurseries, key concerns centred around how compliance with standards would be monitored and how inclusive the scheme would be, recognising that for a biosecurity accreditation scheme to be effective it would need to include all key players. A previous study into the general publics' tree and plant purchasing decisions demonstrated the importance of perceptions of quality and cost over biosecurity precautions and the associated mitigation of damage to the wider environment from pests and diseases, for which awareness is low. Although many supported the notion of an accreditation scheme underpinned by best-biosecurity practice they also expressed concern over whether a nursery's requirement to implement practices and join a scheme would impact the affordability of products [29].

The fundamental components that will facilitate biosecurity behaviours and widescale recruitment to an accreditation scheme include whether the actions or interventions are seen as do-able (it is possible to make changes on-site and within the supply chain), affordability (the benefits of changes/improvements outweigh the costs), benefits (promotes biosecurity), attractiveness (consumers want products from accredited nurseries), fairness and inclusivity (everyone has responsibility for biosecurity); and transparency (the scheme has a strong monitoring and auditing component). The COM-B framework can support the identification of drivers and barriers for specific behaviour(s) and facilitate the development 
of appropriate interventions. We have uncovered how behavioural conditions-the COM-B dimensions-have influenced the appetite amongst nurseries for joining an accreditations scheme to improve and standardise biosecurity behaviours. The rising political profile of plant health in the UK has presented a significant opportunity for highlighting the role of nurseries in collectively managing biosecurity and preventing further incursions $[27,28,37]$. The COM-B framework is a core component of the behaviour change wheel with capability, opportunity and motivation at the centre surrounded by nine intervention functions such as training, coercion, incentivisation, persuasion, education, restrictions, restructuring, modelling, enablement [30]. These interventions are linked to seven policy categories that the authors suggest can be used to deliver the interventions including regulation, legislation, service provision, communication/marketing, environmental/social planning, guidelines and fiscal measures $[30,31]$.

Taking these intervention functions and policy categories into account we identify the following actions to further improve uptake of an accreditation scheme for better biosecurity. This study highlighted knowledge gaps around certain practices (e.g., waste management) and the need for additional targeted information and plant health training to be provided. Any guidelines or service providers such as training must remove uncertainty around what is best practice. An accreditation scheme could act as a consistent and reliable source of best practice evidence, removing the need for nurseries to search within the wide spectrum of available information that may turn out to be misleading or out-of-date. The issue of fairness and the need for accreditation to apply to the whole value chain is challenging, particularly as schemes are normally voluntary rather than mandatory. However, trust will be an important component, particularly in how biosecurity behaviours are monitored and policed within a scheme. Several mechanisms are likely to be needed ranging from restrictions (e.g., rules of membership) and coercion (e.g., there is a cost for unacceptable behaviour) through to enablement (e.g., providing support and acknowledgement for improvements in site biosecurity if radical change is not possible).

Peer pressure may also increase willingness to join a plant health accreditation scheme. For example, education and persuasion will be important interventions where the benefits of accreditation are championed through early adopters and a commitment is made to the scheme from influential customers, membership networks and government. Further incentivisation could come in the form of increased market share, particularly if larger customers include accreditation as a condition of supply. Although this advantage is unlikely to persist if the scheme aims to encapsulate all nurseries, it will nevertheless provide reputational benefits. It will be essential to gain the support of key customers as consumer demand is a major motivation and an important first step in raising awareness of plant health accreditation in the wider public arena. As an accreditation scheme grows, there is the possibility of a positive feedback loop-more goods from accredited sources for sale will lead to greater sales of goods from accredited sources. There is also a huge opportunity for an accreditation scheme and the appearance of its goods on retail shelves to contribute to the education of society about plant health risks. A plant health accreditation scheme will need to clearly state the benefits of membership to outweigh the costs of joining and implementing or improving biosecurity practices. A larger market share from supportive customers may help to address initial costs but other fiscal incentives are likely to be needed to support nurseries, particularly smaller businesses. Indeed, one of the aspirations cited by nurseries was that a scheme could provide insurance or a financial safety net for its members if they have followed all the protocols but are still negatively affected by a pest or disease outbreak. To address concerns about changing current practices that already work well, an accreditation scheme could provide a tiered or flexible system that acknowledges individual nursery contexts and recognises improvements made.

\section{Conclusions}

Plant biosecurity in the UK is steadily rising up the political agenda with increasing awareness of plant health amongst key players who grow and trade in plants. Nurseries 
represent an important bedrock of biosecurity behaviours and our research highlights the benefits and challenges of a host of biosecurity measures as perceived by this key sector. We explored attitudes towards a hypothetical accreditation scheme but acknowledge the recent launch of the Plant Healthy certification scheme in the UK which aims to improve and standardise nursery biosecurity practices. Our research explored nursery and consumer perspectives within the framework of COM-B to identify underlying values, experiences and concerns which will provide important insights for the development of current and future schemes. Consumer demand will be a necessary motivation and a highly publicised accreditation scheme that is embedded with the nation's psyche rather like FSC or Fairtrade would benefit consumers, retailers and the environment. Nevertheless, the concept of a plant health accreditation scheme has applicability beyond the UK borders and would have a far greater impact in the battle to keep our natural environment healthy if membership had a European and global reach.

Author Contributions: M.M., M.D. and S.G. Research Design and recruitment; M.D. Interviews. All authors have read and agreed to the published version of the manuscript.

Funding: This research was supported by a grant funded jointly by the Biotechnology and Bio-logical Sciences Research Council, the Department for Environment, Food and Rural affairs, the Economic and Social Research Council, the Forestry Commission, the Natural Environment Research Council and the Scottish Government, under the Tree Health and Plant Biosecurity Initiative, grant number BB/N023463/1. The funders had no role in the collection, analyses or interpretation of the data; in the writing of the manuscript, or in the decision to publish the results.

Data Availability Statement: The interview transcripts have not been shared publicly due to confidentiality. Anonymized data could be shared on reasonable request to the corresponding author.

Acknowledgments: The authors would like to acknowledge the supporting role of James Robinson and Tim Pettitt for supporting data gathered with Local Authority consumers and nurseries respectively.

Conflicts of Interest: The authors declare no conflict of interest.

\section{References}

1. Yeomans, A.; Tim, A. AIPH International Plant Health Survey; AIPH: Oxfordshire, UK, 2021.

2. CONFOR [Confederation of Forest Industries Ltd.]. Update on New Biosecurity Measures. 2020. Available online: confor.org.uk (accessed on 21 June 2021).

3. Freer-Smith, P.; Webber, J. Tree pests and diseases: The threat to biodiversity and delivery of ecosystem services. Biodivers. Conserv. 2017, 26, 3167-3181. [CrossRef]

4. Potter, C.; Urquhart, J. Tree diseases and pest epidemics in the Anthropocene: A review of the drivers, impacts and policy responses in the UK. Forest Policy Econ. 2017, 79, 61-68. [CrossRef]

5. Hill, L.; Jones, G.; Atkinson, N.; Hector, A.; Hemery, G.; Brown, N. The $£ 15$ billion cost of ash dieback in Britain. Curr. Biol. 2019, 29, R315-R316. [CrossRef] [PubMed]

6. Brasier, C.M.; Webber, J.F. Sudden larch death. Nature 2010, 466, 824-825. [CrossRef]

7. Jung, T.; Orlikowski, L.; Henricot, B.; Abad-Campos, P.; Aday, A.G.; Aguín Casal, O.; Bakonyi, J.; Cacciola, S.O.; Cech, T.; Chavarriaga, D.; et al. Widespread Phytophthora infestations in European nurseries put forest, semi-natural and horticultural ecosystems at high risk of Phytophthora diseases. For. Pathol. 2016, 46, 134-163. [CrossRef]

8. Green, S.; Cooke, D.E.L.; Dunn, M.; Barwell, L.; Purse, B.; Chapman, D.S.; Valatin, G.; Schlenzig, A.; Barbrook, J.; Pettitt, T.; et al. PHYTO-THREATS: Addressing threats to UK forests and woodlands from Phytophthora; Identifying risks of spread in trade and methods for mitigation. Forests 2021, 12, 1617. [CrossRef]

9. Alonso-Chavez, V.; Parnell, S.; Vandenbosch, F. Monitoring invasive pathogens in plant nurseries for early detection and to minimise the probability of escape. J. Theor. Biol. 2016, 407, 290-302. [CrossRef]

10. Nursery Industry Accreditation Scheme in Australia. Available online: ngiwa.com.au (accessed on 19 July 2021).

11. The New Zealand Plant Pass Scheme. Available online: https://www.plantpass.org.nz/biosecuurity/resource (accessed on 19 July 2021).

12. Global GAPP Trademark and Certification. Available online: www.globalgap.org.uk (accessed on 19 July 2021).

13. Plant Healthy Certification Scheme. Available online: https:/ / planthealthy.org.uk (accessed on 19 July 2021).

14. Ornamental Horticulture Assurance Scheme OHAS. Available online: hta.org.uk/partnerships-groups/ohas (accessed on 19 July 2021).

15. United Kingdom Accreditation Service (UKAS). Available online: www.ukas.com (accessed on 19 July 2021). 
16. Gulbrandsen, L.H. Creating markets for eco-labelling: Are consumers insignificant? Int. J. Consum. Stud. 2006, 30, 477-489. [CrossRef]

17. Eden, S.; Bear, C.; Walker, G. Understanding and (dis) trusting food assurance schemes: Consumer confidence and the 'knowledge fix'. J. Rural Stud. 2008, 24, 1-14. [CrossRef]

18. Nilsson, H.; Tunçer, B.; Thidell, $\AA$. The use of eco-labeling like initiatives on food products to promote quality assurance-is there enough credibility? J. Clean. Prod. 2004, 12, 517-526. [CrossRef]

19. Zaman, A.U.; Miliutenko, S.; Nagapetan, V. Green marketing or green wash?: A comparative study of consumers' behavior on selected Eco and Fair trade labeling in Sweden. J. Ecol. Nat. Environ. 2010, 2, 104-111.

20. Fearne, A.; Hornibrook, S.; Dedman, S. The management of perceived risk in the food supply chain: A comparative study of retailer-led beef quality assurance schemes in Germany and Italy. Int. Food Agribus. Manag. Rev. 2001, 4, 19-36. [CrossRef]

21. Janssen, M.; Hamm, U. Product labelling in the market for organic food: Consumer preferences and willingness-to-pay for different organic certification logos. Food Qual. Prefer. 2012, 25, 9-22. [CrossRef]

22. ADAS UK Ltd. Scoping Study on Tree and Shrub Nursery Labelling/Accreditation/Assurance Scheme; Defra: London, UK, 2014.

23. UKFS. The UK Forestry Standard-GOV.UK. Available online: www.gov.uk (accessed on 19 July 2021).

24. Auld, G.; Gulbrandsen, L.H.; McDermott, C.L. Certification schemes and the impacts on forests and forestry. Annu. Rev. Environ. Resour. 2008, 33, 187-211. [CrossRef]

25. Curtis, D.J.; Gill, N.J.; Atchison, J.M.; McKiernan, S. Plant Sure Environmentally Safe Ornamental Plant Scheme: Review of existing certification or accreditation schemes and recommendations for a model scheme. Fac. Soc. Sci. -Pap. 2018, 4141. Available online: https: / / ro.uow.edu.au/sspapers (accessed on 19 July 2021).

26. Valatin, G.; Price, C.; Green, S. Reducing disease risks to British forests: An exploration of costs and benefits of nursery best practices. Forestry 2021. in review.

27. Department for Environment, Food and Rural Affairs. Tree Health Resilience Strategy. Building the Resilience of Our Trees, Woods and Forests to Pests and Diseases. 2018. Tree Health Resilience Strategy 2018-GOV.UK. Available online: www.gov.uk (accessed on 20 July 2021).

28. UK Government. The England Trees Action Plan 2021-2024. Available online: www.gov.uk (accessed on 20 July 2021).

29. Dunn, M.; Marzano, M.; Forster, J. Buying better biosecurity: Plant buying behaviour and the implications for an accreditation scheme in the horticultural sector. Plants People Planet 2020, 2, 259-268. [CrossRef]

30. Michie, S.; Van Stralen, M.M.; West, R. The behaviour change wheel: A new method for characterising and designing behaviour change interventions. Implement. Sci. 2011, 6, 42. [CrossRef] [PubMed]

31. Michie, S.; Atkins, L.; West, R. The Behaviour Change Wheel; Silverback Publishing: Sutton, UK, 2014; pp. 1-333.

32. PHYTO-THREATS Project. Global threats from Phytophthora spp. (PHYTO-THREATS)—Forest Research. Available online: https:/ / www.forestresearch.gov.uk/research/global-threats-from-phytophthora-spp/ (accessed on 30 July 2021).

33. Parke, J.L.; Grünwald, N.J. A Systems Approach for Management of Pests and Pathogens of Nursery Crops. Plant. Dis. 2012, 96, 1236-1244. [CrossRef] [PubMed]

34. Parke, J.L.; Knaus, B.J.; Fieland, V.J.; Lewis, C.; Grünwald, N.J. Phytophthora Community Structure Analyses in Oregon Nurseries Inform Systems Approaches to Disease Management. Phytopathology 2014, 104, 1052-1062. [CrossRef] [PubMed]

35. Bryman, A. Social Research Methods; Oxford University Press: Oxford, UK, 2001; p. 540.

36. Robson, C. Real World Research, 2nd ed.; Oxford University Press: Oxford, UK, 2002; p. 586.

37. Scrace, J.; Slawson, D.; Beales, P. Nurseries, Retailers, Landscapers-Biosecurity Best Practice Protocols; Fera: York, UK, 2012. 